KEYWORDS

Economic growth

Balance of payments

Gross Domestic Product

Imports

Exports

Data analysis

Mathematical models

Cuba

Pavel Vidal Alejandro

Professor, Centre for the Study

of the Cuban Economy (CEEC)

University of Havana

$\leadsto$ pavel@uh.cu

Annia Fundora Fernández

Professor, Department of

Macro- and Microeconomics

University of Havana

$\infty$ annia@fec.uh.cu
CEPAL REVIEW 94 • APRIL 2008

\section{Trade-growth relationship in Cuba: estimation using the Kalman filter}

\author{
Pavel Vidal Alejandro and Annia Fundora Fernández
}

I

this article, time-varying coefficients are used to estimate the balance of payments constrained growth (BPCG) model for Cuba. Exports are considered to have been a decisive factor in Cuba's recovery following the crisis. Also, there was an estimated increase in income elasticity of demand for imports in the early 1990s and between 2003 and 2005, indicating a decrease in import substitution. The conclusion is that, given the rapid rise in the export of services, there are now better growth prospects for the Cuban economy. However, prospects could be better and would benefit a larger share of the economy if import substitution were also made more efficient and other export sectors with a greater multiplier effect were expanded. 
I

\section{Introduction}

In this article, time-varying coefficients are used to estimate the balance of payments constrained growth model for Cuba. The extended form of the BPCG model is used to explain economic growth based on exports, external financing and terms of trade.

The subject has already been addressed in studies by Moreno-Brid (2000), Mendoza and Robert (2002), Mañalich and Quiñones (2004), Alonso and SánchezEgozcue (2005) and Cribeiro and Triana (2005). All these studies estimate the trade-growth relationship in Cuba. The contribution this article makes is to use the Kalman filter (KF) estimation method and state-space representation to estimate equations with time-varying coefficients. The aim is to ascertain the trajectory of the elasticities associated with the explanatory variables of the BPCG model, as well as their contribution during different periods. The article also analyses the evolution of import substitution, using the estimated trajectory of income elasticity of demand for imports.

The basic hypothesis is that, in the period 19502005, the Cuban economy underwent a number of phases that may have modified the relationship between economic growth and the balance of payments.
Between 1950 and 1959, Cuba was a market economy; after 1960 it began to function as a centrally-planned economy; in 1973 it entered the Council for Mutual Economic Assistance (CMEA) with the then-socialist countries; as from 1990 it was affected by the disintegration of the Soviet Union and the collapse of the European socialist block, and now it has stepped up its pace of growth by concluding new agreements with Venezuela and China.

The article is structured as follows. Section II explains the balance of payments constrained growth (BPCG) model. Section III discusses the data. Section IV presents the cointegration tests and the recursive and sequential estimations of the coefficients. The results obtained in section IV are used to estimate the timevarying parameter model; taking a Bayesian approach, they can be interpreted as prior information. Section $\mathrm{V}$ presents the model in the state-space form and the statistical results of the Kalman filter. Section VI describes the trajectory of the elasticities and discusses the contribution of the model's explanatory variables. Finally, the conclusions assess the principal results.

\section{II}

\section{Balance of payments constrained growth model}

The BPCG model, initially put forward by Thirlwall (1979), follows the Keynesian approach of stressing the importance of aggregate demand in the economic growth process, as opposed to the neoclassical approach, which considers the supply of factors of production and technical progress to be fundamental elements of growth. Of the components of aggregate demand, the BPCG model emphasizes the role of exports, as these are the only component of demand that can be expanded without destabilizing the balance of payments situation. The model also reflects the fact that GDP is determined by income elasticity of demand for imports; an increase in such elasticity reduces the export multiplier effect.
Thus, given its rate of export growth and income elasticity of imports, each country has a GDP growth rate consistent with the current account balance. Thirlwall and Hussain (1982) extend the model to include net external financing; this makes it possible to reflect the experience of countries that accumulate current account deficits for prolonged periods. ${ }^{1}$

The BPCG model can reflect the situation of countries like Cuba, which rely on imported intermediate

\footnotetext{
${ }^{1}$ For a fuller description of the BPCG model, see McCombie and Thirlwall (1994).
} 
inputs for the day-to-day running of the economy and on imported capital goods to increase growth in productive forces. Thus, economic growth is constrained by the availability of foreign exchange to finance imports.

Exports affect growth in gross domestic product (GDP) in two ways: first, via the foreign trade multiplier and, second, by relaxing the balance of payments constraint on growth, as exports automatically generate foreign exchange receipts to pay for imports. That is why, even if the value of exports is small compared with the total value of GDP, export growth is a decisive factor in total growth. Added to the effect of exports, there is also the relaxing effect that external financing and terms of trade can have on balance of payments constraints.

Below is the formulation of the extended form of the BPCG model developed by Thirlwall and Hussain (1982).

$$
X^{*} P x+F E^{*} E=M^{*} P m^{*} E
$$

Equation (1) expresses the balance of payments identity, where $X$ represents real exports, $P x$ is the price of exports in national currency, $F E$ is net external financing or the current account deficit in foreign currency units, $M$ is real imports, $P m$ is the price of imports in foreign currency and $E$ is the nominal exchange rate expressed in national currency units per foreign currency unit.

$$
\theta=\frac{P x * X}{(P x * X+F E * E)}
$$

Equation (2) is an identity introduced to simplify the algebraic notation, in which $\theta$ expresses export earnings as a share of total imports at current prices and $(1-\theta)$ expresses the proportion of current imports financed with the net capital inflow. The dynamic formulation of equation (1) is:

$$
\theta(x+p x)+(1-\theta)(f e+e)=m+p m+e
$$

where the lower-case letters represent the growth rates of the variables.

Expression (4) below symbolizes a conventional dynamic equation of import demand, and equation (5) expresses exports as exogenous to the other variables in the model:

$$
m=\phi(p m-p x+e)+\xi y \text { with } \phi<0 \mathrm{y} \xi>0
$$$$
\text { (5) } \quad x=x_{0}
$$

where $\theta$ is the import price elasticity, $y$ is the growth rate of real national income and $\xi$ is the income elasticity of imports.

By substituting equations (4) and (5) into expression (3) and taking a fixed exchange rate $(e=0)$, we obtain the economic growth rate compatible with the balance of payments equilibrium:

$$
y=\frac{\theta x+(1-\theta)(f e-p x)+(\phi+1)(p x-p m)}{\xi}
$$

Equation (6) expresses the growth rate in real national income as determined by the rates of: export growth $(x)$, net external capital flows in real terms ( $f e$ $-p x)$ and the terms of trade $(p x-p m)$. The expectation is a positive relationship with exports and external financing $;^{2}$ in the case of the terms of trade, the sign depends on the value of $\phi$. Equation (6) also reflects the fact that economic growth is determined by income elasticity of demand for imports $\xi$. A decrease in $\xi$ is associated with a process of import substitution; equation (6) indicates that such a process has a positive impact on economic growth. A stochastic representation of equation (6) is estimated using Cuban data. ${ }^{3}$

\section{Latest revisions of the model}

Although in this article we estimate only model (6), which in the case of Cuba has never before been estimated to include external financing, below is a summary of two more recent revisions of the BPCG model.

Moreno-Brid (1998-1999) developed a new version to guarantee that the balance of payments-constrained growth rate is accompanied by a sustainable increase

\footnotetext{
2 This assumes that the country is a net importer of capital and therefore $\theta$ is less than one unit. On the assumption that there ought not to be a long-term current account deficit $(\theta=1)$ and that the terms of trade do not change, this gives the simplest form of the BPCG model: long-term growth is determined by the export growth rate and income elasticity of imports. In literature, this expression is known as the dynamic Harrod foreign trade multiplier, or Thirlwall's Law: $y=\frac{x}{\xi}$

${ }^{3}$ See Atesoglu (1993-1994) and Hussain (1999) for estimations of the BPCG model extended to include external financing.
} 
in external debt. He redefines the notion of long-run balance of payments equilibrium by introducing a constant quotient $\mathrm{B}$ for the current account deficit in relation to domestic income, with both variables measured in nominal terms:

$$
B=\frac{\left(P m^{*} M-P x * X\right)}{(P * Y)}
$$

By differentiating this expression and equalling it to zero, and adding in the functions of import demand (4) and exogenous exports (5), we arrive at a new expression for balance of payments constrained growth:

$$
y=\frac{\theta x+(\phi+1)(p x-p m)}{\xi-1+\theta}
$$

Although this still depends on exports and the terms of trade, the value of the long-run multipliers is altered by a factor equal to $\frac{\xi}{\xi-1+\theta}$

The second revision was developed by MorenoBrid (2003), by explicitly taking into account the influence of interest payments in the rate of economic growth compatible with the balance of payments equilibrium. This proves to be an important amendment for analysing the long-term growth pattern of developing economies where net interest payments are a major component of their current deficit.

To arrive at the final expression of the model, the following equations are added to the functions of imports (4), exports (5) and the constraint (7):

$$
p m+m=\theta_{1}(p x+x)-\theta_{2}(r+p x)+\left(1-\theta_{1}+\theta_{2}\right)(f+p x)
$$

$$
\theta_{1}=\frac{P x^{*} X}{P m^{*} M}
$$

$$
\theta_{2}=\frac{P x^{*} R}{P m^{*} M}
$$

where equation (9) corresponds to the dynamic expression of the balance of payments identity and includes $r$ as net interest payments abroad and $f$ as external capital flows, both measured in growth rates and in real terms. By solving the system of equations, we arrive at the following expression for the balance of payments-constrained growth rate:

$$
y=\frac{\theta_{1} x-\theta_{2} r+(1+\phi)(p x-p m)}{\xi-\left(1-\theta_{1}+\theta_{2}\right)}
$$

The sign of the multiplier associated with the growth in net interest payments indicates the negative impact of interest payments on income growth; it imposes an additional constraint, in the sense that a portion of the current income that could be used to pay for imports must instead be used to step up interest payments. Hence the importance of maintaining prudent levels of debt, given that the effect of increasing the amount of external financing is to also increase net interest payments abroad. ${ }^{4}$

Moreno-Brid and Ricoy (2005) set out the successive versions of the BPCG model and empirically prove the predictive power of each version with reference to the Mexican economy during the period 1967-1999.

\footnotetext{
${ }^{4}$ Moreno-Brid (1998-1999) and Moreno-Brid (2003) develop the theoretical formulation of the model, using a conventional function of real export demand rather than exogenous export demand.
} 


\section{III Data}

The data used are annual series from 1950 to 2005 for GDP based on 1997 values, real exports of goods and services (X), net actual external financing (FE), as well as the terms of trade (ТOT) calculated by the quotient between the export price index for goods and services and the import price index for goods and services. The data are drawn from the yearbooks of Cuba's National Statistical Office (ONE) and its National Institute of Economic Research (INIE).

The data on actual external financing are obtained by dividing the current account deficit by an average between the export price index and the import price index. Twice the minimum value is added to the entire series to avoid having negative data in the years where there was a current account surplus; thus the logarithmic transformation can be applied to obtain the elasticity (see appendix A).

Figure 1 presents the evolution of the series. All the series follow a non-stationary trajectory with an order of integration of one, or I(1). Table 1 shows the result of the augmented Dickey-Fuller test (ADF). ${ }^{5}$

The graph on real GDP in Figure 1 shows a sharp fall in the early 1990s, totalling a $35 \%$ decrease in the first four years of the decade and marking an economic crisis known as Cuba's 'Special Period'. There was also a drop in the remaining series in the early 1990s. It is therefore not necessary to include in the model qualitative intervention variables to capture the fall in GDP during these years, since it is explained within the BPCG model itself. As from 1995, GDP resumed its upward trend. The latest available observations reveal growth of $5.4 \%$ in 2004 and $11.8 \%$ in 2005 .

In the series of real exports of goods and services, there was a recovery following the fall in the early 1990s. In 2004, real exports of goods and services grew by $19 \%$ and, in 2005 , by $46 \%$ (the largest increase of the period under analysis). There was also a qualitative change in exports. Up until the late 1980s, exports were dominated by primary goods (first sugar, followed by nickel, tobacco and fisheries), which together accounted for more than $70 \%$ of total exports. In the 1990 s, a process of tertiarization of exports began, initially triggered by the expanding tourism sector and, after 2003, driven by the export of professional services, especially the sale of medical services to Venezuela. In 2005, services accounted for more than $70 \%$ of total exports.

The net external financing series highlights the growth in the 1980s. Just as in other countries in the region, Cuba received petrodollar loans from private financial institutions and governments in the rest of the world. Credits also arrived from the block of socialist countries, entailing advantageous credit-term and interest-rate conditions. External debt spiralled so high that, in 1986, Cuba declared a moratorium on the repayment of foreign-currency debt. In the early 1990s, there was a compulsory current account adjustment. Net external financing fell again in 2004 and 2005, this time because the balance-of-payments current account recorded a surplus after being constantly in deficit since 1961.

The history of the terms of trade has also been marked by the same events. With Cuba's entry into the CMEA and its conclusion of agreements that guaranteed a secure market for exports and preferential prices for sugar exports and oil imports, the terms of trade improved by more than $90 \%$ between 1973 and 1975. By the 1980s, they had already begun to show a negative trend, which worsened in the early 1990s owing to the collapse of the European socialist block, with which Cuba conducted around $85 \%$ of its trade.

Imports and external financing as a proportion of GDP have been on a declining trend (table 2). The export share of GDP also diminished in the 1960s, 1970s and 1980s, but increased in the 1990s and, in the twenty-first century, is averaging $19.8 \%$, which is the highest share since the 1970s.

\footnotetext{
${ }^{5}$ The results of the unit root test could be influenced by the presence of structural changes in the series. The sheer variety of possible structural-break dates precluded use of the Perron test (1989). Subsequently, the recursive and sequential estimations of the model revealed no single break point in the estimation period.
} 
FIGURE 1

Cuba: evolution of the series, 1950-2005

(Logarithm of data)
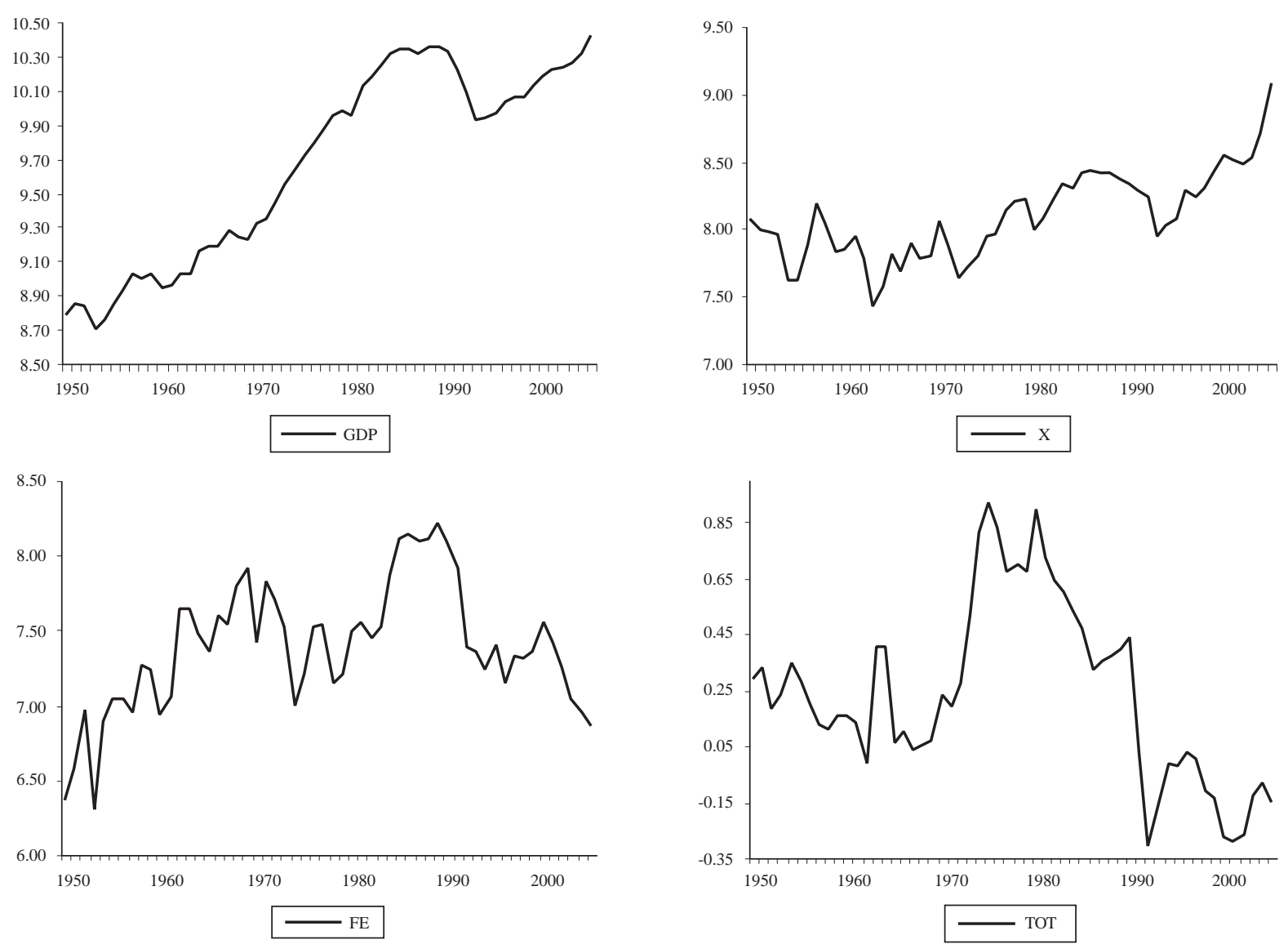

Source: Author, on the basis of data from Cuba's National Statistical Office (ONE) and its National Institute of Economic Research (INIE).

a GDP: gross domestic product. X: exports. FE: external financing. TOT: terms of trade

TABLE 1

Cuba: test for stationarity of the series, period 1950-2005a

(Statistical results with the logarithm of data)

\begin{tabular}{lccc}
\hline Series & ADF $^{\mathrm{b}}$ & Constant and trend & Lags \\
\hline GDP & 1.98 & No & 1 \\
X & -2.52 & Yes & 0 \\
FE & -2.08 & Constant & 4 \\
TOT & -1.41 & No & 0 \\
First difference & & & \\
D(GDP) & $-4.91^{*}$ & Constant & 0 \\
D(X) & $-6.21^{*}$ & No & 0 \\
D(FE) & $-3.03^{*}$ & No & 3 \\
D(TOT) & $-6.43^{*}$ & No & 0 \\
\hline
\end{tabular}

Source: Author.

a Stationary at $5 \%$.

b Augmented Dickey-Fuller test.
TABLE 2

Cuba: real value of exports, imports and external financing as a proportion of real GDP (Annual averages in percentage terms)

\begin{tabular}{lccc}
\hline Years & X/GDP & M/GDP & FE/GDP \\
\hline $1950-1959$ & 39.0 & 47.1 & -1.5 \\
$1960-1969$ & 25.9 & 38.5 & 8.2 \\
$1970-1979$ & 18.5 & 38.4 & 8.2 \\
$1980-1989$ & 14.2 & 30.6 & 5.4 \\
$1990-1999$ & 15.6 & 18.5 & 2.8 \\
$2000-2005$ & 19.8 & 17.2 & 1.0 \\
\hline
\end{tabular}

Source: Author, on the basis of data from Cuba's National Statistical Office (ONE) and its National Institute of Economic Research (INIE).

TRADE-GROWTH RELATIONSHIP IN CUBA: ESTIMATION USING THE KALMAN FILTER • PAVEL VIDAL ALEJ ANDRO AND ANNIA FUNDORA FERNÁNDEZ 


\section{IV}

\section{Cointegration and recursive and sequential estimations}

On the basis of equation (6) in the BPCG theoretical model, based on the same order of integration for all the series, a test is conducted to determine whether there is a long-run relationship between the variables GDP, X, FE and TOT (table 3). Using the Engle-Granger methodology (1987), the augmented Dickey-Fuller test is carried out on the estimation residues using the ordinary least squares method (OLS) of equation (13). ${ }^{6}$

$$
\begin{gathered}
\log P I B_{t}=\beta_{0}+\beta_{1} * \log X_{t}+\beta_{2} * \log F E_{t}+ \\
\beta_{3} * \log \text { TOT } \\
t+\beta_{4} * \text { Trend }+e_{t}
\end{gathered}
$$

The value of the ADF statistic is compared with the critical values reported in Engle and Yoo (1987). The Johansen methodology (1991 and 1995) is also applied, and the value of the trace statistic is compared with the critical values reported by Johansen and Juselius (1990). At the 10\% significance level, both tests find cointegration to be present.

Table 4 shows the cointegration vector estimation by Engle and Granger and by Johansen. In both cases, the inclusion of trend in the cointegration vector caused the adjusted $\mathrm{R}^{2}$ to rise and the Akaike information criterion (AIC test) to fall; in fact, if the trend is excluded, no long-run relationship between the variables is found. The trend is always significant. ${ }^{7}$ Also, the variables for exports, external financing and terms of trade are significant in the different estimations and their sign tallies with economic theory.

${ }^{6}$ Even when the theoretical model is expressed in growth rates, a growing number of empirical studies make the estimations using the logarithm levels of the series, so as to avoid losing the long-term information with the differentiation. See for example Bairam (1993), Atesoglu (1997) and Moreno-Brid (1999).

${ }^{7}$ Blecker's interpretation (1992, pp. 338-339) includes a trend in the BPCG model. According to Blecker, the trend does not have to change the direction of the BPCG model's growth equation and can continue to represent the growth rate compatible with the balance of payments equilibrium; the trend would seem to stem from the existence of structural trends in export and/or import demand that define the longterm evolution of the country's relative competitiveness. McCombie (1997) also uses trend in his estimations.
The studies of Mendoza and Robert (2002) and Cribeiro and Triana (2005), based on the Chow test and the cumulative sum (CUSUM) test for structural change, find parameter instability in the BPCG model estimations for Cuba. Even though the other studies mentioned do not test this assumption statistically, they make estimations for different periods and obtain values that differ from the elasticities.

TABLE 3

Cuba: cointegration test, period 1950-2005, GDP, $X, F E$ and TOT series ${ }^{a b}$

(Statistical results with the logarithm of data)

\begin{tabular}{cc}
\hline $\begin{array}{c}\text { Engle-Granger test } \\
\text { Augmented Dickey-Fuller test }\end{array}$ & $\begin{array}{c}\text { Johansen test } \\
\text { Trace test }\end{array}$ \\
\hline$-4.21^{\mathrm{c}}$ & $60.34^{\mathrm{c}}$ \\
\hline
\end{tabular}

Source: Author.

a Constant and trend were included.

b The Johansen test was conducted with two lags.

There is cointegration at $10 \%$.

TABLE 4

Cuba: cointegration vector ${ }^{a}$

(Statistical results with the logarithm of data)

\begin{tabular}{lll}
\hline & Engle-Granger test $^{\mathrm{b}}$ & $\begin{array}{c}\text { Johansen test } \\
\text { (with two lags) }\end{array}$ \\
\hline GDP & 1.00 & 1.00 \\
$\mathrm{X}$ & $0.48(0.05)$ & $0.46(0.06)$ \\
$\mathrm{FE}$ & $0.24(0.03)$ & $0.24(0.03)$ \\
TOT & $0.49(0.04)$ & $0.59(0.04)$ \\
Trend & $0.026(0.001)$ & $0.026(0.001)$ \\
Constant & $3.14(0.49)$ & 3.22 \\
$\begin{array}{l}\text { Akaike information } \\
\quad \text { criterion }\end{array}$ & -2.17 & -5.30 \\
Adjusted $\mathrm{R}^{2}$ & 0.98 & \\
\hline
\end{tabular}

Source: Author.

a In the vector the coefficients do not take the opposite sign. The figures in brackets correspond to standard error.

b Results in the first step of the Engle-Granger methodology. 
FIGURE 2

Cuba: recursive estimations (1960-2005) and sequential estimations (1970-2005) with sampling windows of 20 and $\mathbf{2 5}$ observations ${ }^{a}$ b

(Statistical results with the logarithm of data)

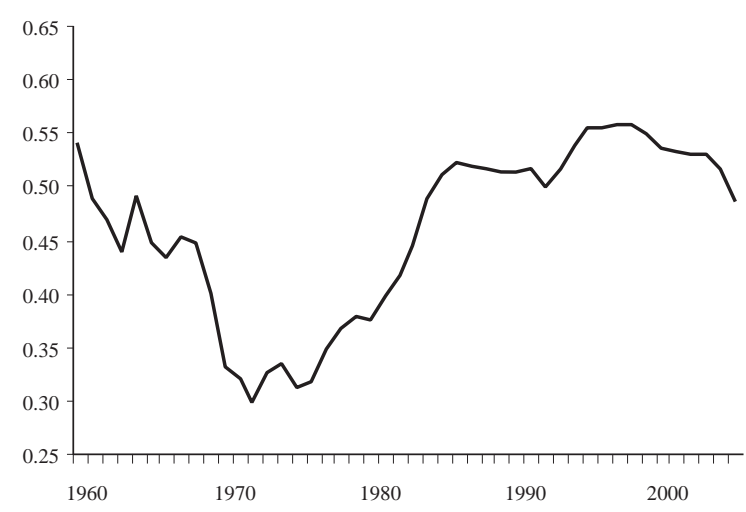

$\beta_{1}$

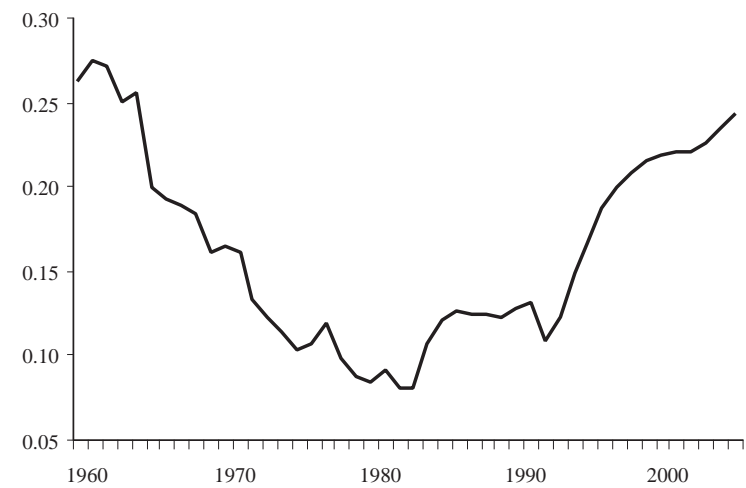

$\beta_{2}$
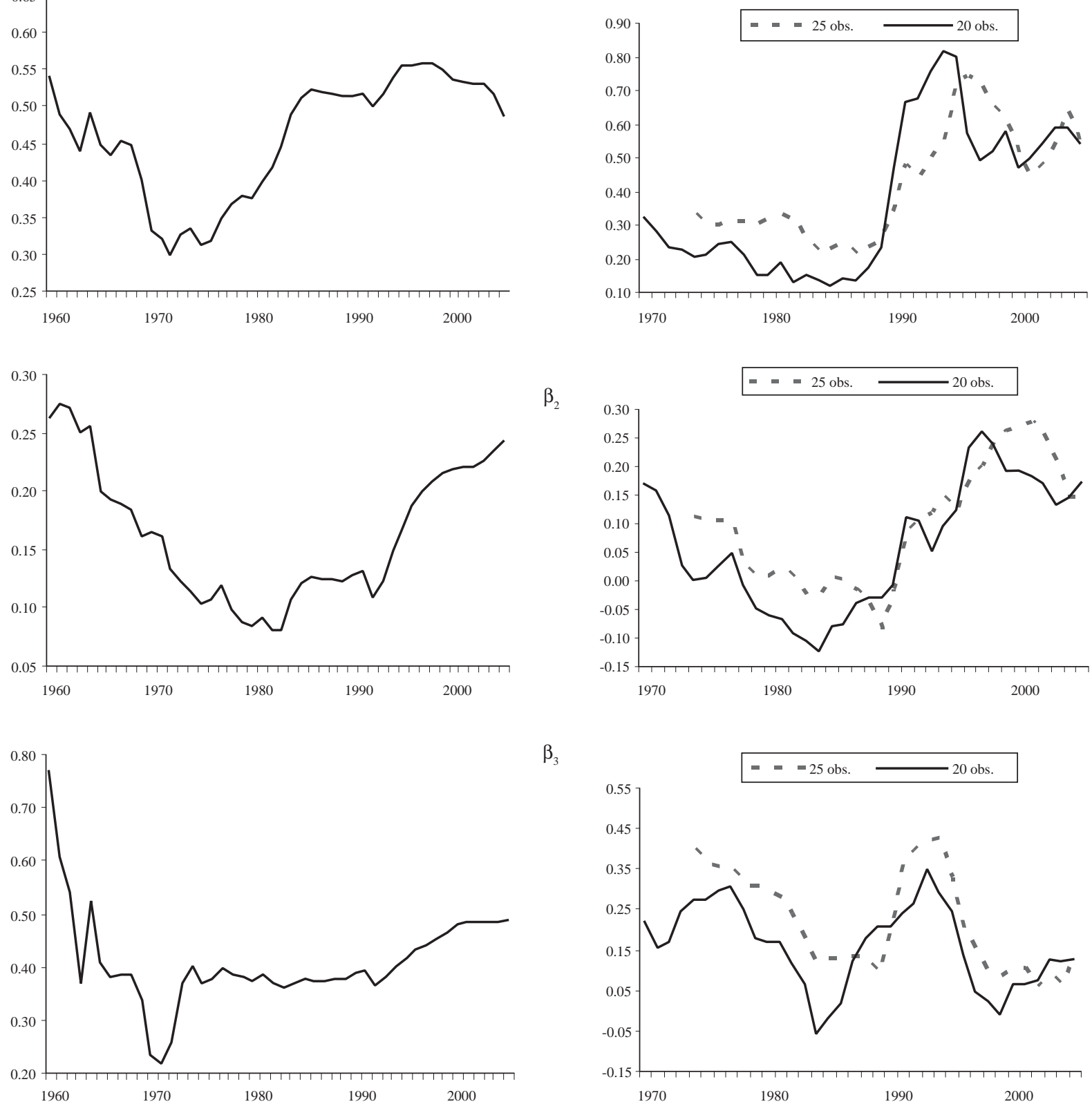

$\beta_{3}$

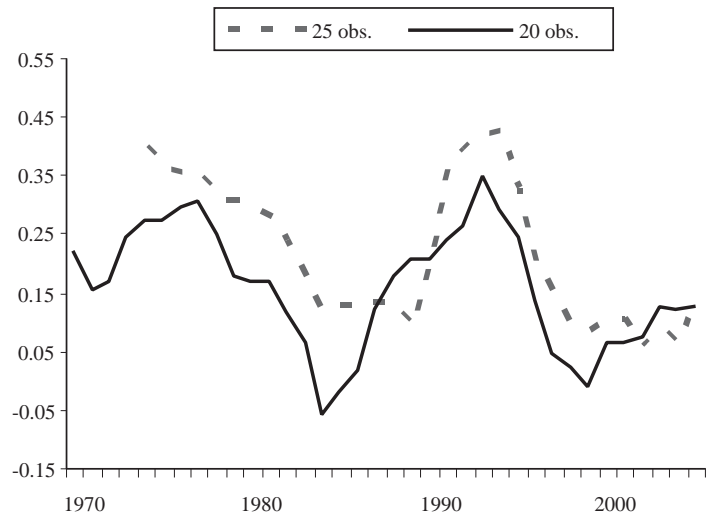

Source: Author.

a In the recursive estimations, the model was estimated repeatedly, each time adding a new observation. Sequential estimations, unlike recursive estimations, keep a constant sample size. These are successive estimations of size $\mathrm{n}$ for which two sampling windows are used: $\mathrm{n}=20 \mathrm{y} \mathrm{n}=25$. In the figures, the estimation of the coefficient of a window was assigned to the last year of the corresponding period.

b Model: $\log P I B_{t}=\beta_{0}+\beta_{1} * \log X_{t}+\beta_{2} * \log F E_{t}+\beta_{3} * \log T O T_{t}+\beta_{4} *$ Trend $+e_{t}$ 
This would seem a logical concern, in view of the fact that, during the 55-year period used for the estimations, the Cuban economy underwent a number of phases that may have altered the relationship between economic growth and the balance of payments. In addition, parameter instability is also expressed in the BPCG theoretical model itself, the extended form of which includes external financing. Equation (6) shows that the coefficients for exports and external financing depend on $\theta$ (the quotient between current exports and current imports), which is not generally constant over time. In the case of Cuba, it has ranged around an average value of 0.87 , with a standard deviation of $0.13 .^{8}$ In the latest formulations (equations 8 and 12) the multipliers also depend on $\theta$.

To evaluate the parameter stability statistically, this article used the recursive residues and the CUSUM test of squares of equation (13) estimated using ordinary least squares; both suggested instability in the model (lack of space prevents the results from being described in this article). In addition, recursive and sequential estimations of $\beta_{1}, \beta_{2}$ y $\beta_{3}$ in equation (13) were computed, clearly showing instability (figure 2). As the figure shows, there appears to be no single break point in the coefficients in either the recursive or sequential estimations. This makes it difficult to pinpoint the date of the structural changes. Not only do the coefficients change much of the time, they do not have the same trajectory and the date of the maximums and minimums does not coincide. The parameter instability does not appear to be of the sort that can be resolved by including qualitative intervention variables in the model, or by working with estimations in different periods.

There are a number of drawbacks with using recursive and sequential estimations to analyse the trajectory of the coefficients. Some of the recursive estimations are done using too small a sample size, compounding the inaccuracy. There is a wide standard deviation in both the recursive and sequential estimations. In the sequential estimations, a larger sampling window could have been used to increase accuracy, but this would have meant losing much of the information on the trajectory of the coefficients. Furthermore, the recursive or sequential estimation for each year excludes information contained in part of the 1950-2005 sampling period.

Section V makes a dynamic representation of equation (6) in state-space form and an estimation of the coefficients using the Kalman filter. A stochastic trajectory of the coefficients is estimated instead of a deterministic trajectory, with a smaller standard deviation and using all the information from 1950 to 2005.

\section{$\mathrm{V}$}

\section{Model with time-varying coefficients}

\section{State-space notation}

State-space models are a convenient notation for a wide range of time-series models. Some of their specific uses include: (i) modelling of non-observable components; (ii) representation of autoregressive integrated moving average (ARIMA) models, and (iii) estimation of time-varying parameter (TVP) models, which is the application that we shall be using here.

\footnotetext{
${ }^{8}$ To estimate the bpcg model with external financing, Hussain (1999) first estimates export demand, from which he obtains the income and price elasticities, which he substitutes into equation 6 (according to the numbering in this article), together with the average observed value of $\theta$. Atesoglu (1993-1994) estimates equation (6) directly, assuming that the parameters are constant.
}

Some of the authors who have applied timevarying parameter models include Nelson and Kim (1988), who studied variations in the reaction function of the United States Federal Reserve System; Haldane and Hall (1991), who investigated the pound sterling's changing relationship with the Deutschmark and the United States dollar, and Revenga (1993) and Álvarez, Dorta and Guerra (2000), who made a stochastic estimation of inflationary persistence in the European Monetary System and in Venezuela, respectively. No published work was found that estimates the BPCG model using time-varying coefficients.

A state-space model is written in terms of a measurement equation (or observation) and a state equation (or transition). The measurement equation describes the relationship between observed variables 
(data) and latent (non-observable) state variables. The state equation describes the dynamics of state variables and usually takes the form of a random walk or a firstorder autoregressive process (AR(1)). A representation of a state-space model can be written as:

\section{Measurement equation}

$$
y_{t}=x_{t} \beta_{t}+e_{t}
$$

State equation

$$
\begin{aligned}
& \beta_{t}=\widetilde{\mu}+F \beta_{t-l}+v_{t} \\
& e_{t} \sim \text { i.i.d. } N(0, \mathrm{R}), \\
& v_{t} \sim \text { i.i.d. } N(0, \mathrm{Q}), \\
& \mathrm{E}\left(e_{t} v_{s}\right)=0
\end{aligned}
$$

where $y_{t}$ is $1 \times 1$ and represents the dependent variable observed at the time $t ; \beta_{t}$ is a vector $k \times 1$ of latent state variables; $x_{t}$ is a vector $1 \mathrm{x} k$ of observed exogenous or predetermined variables that relate the observable vector $y_{t}$ with the latent vector $\beta_{t} ; \widetilde{\mu}$ is a vector $k \mathrm{x} 1$ of constant coefficients to be estimated and $F$ is a matrix of constant parameters of order $k \times k$. The $e_{t}$ of order $1 \times 1$ and the vector $v_{t}$ of order $k \times 1$ represent the errors in the measurement and state equations.

The state vector $\beta_{t}$ must contain the most important information in the system at each point in time. In general, the state vector elements are non-observable. Equation (15) indicates that the new state vector is modelled as a linear combination of the former state vector and of a process of error. Equation (14) describes how the measurements or observations depend on the state vector.

In our case, the long-run relationship that had been estimated between real GDP, real exports, external financing and the terms of trade can be rewritten by adding a subindex $t$ to the coefficients to indicate that they change over time:

$$
\begin{gathered}
\log P I B_{t}=\beta_{0 t}+\beta_{1 t} * \log X_{t}+ \\
\beta_{2 t} * \log F E_{t}+\beta_{3 t} * \log T O T_{t}+e_{t}
\end{gathered}
$$

where $\beta_{i t}$ for $i=0,1,2,3$ are the time-varying coefficients or state variables in this model. Despite the fact that the series are non-stationary, they have been kept at their respective levels because the tests show that they are cointegrated (at the $10 \%$ significance level). The independent term, which could also change over time, will be used to represent the deterministic trend, which was found to be necessary to the long-run relationship.

The state-space representation compatible with equation (16) is as follows:

\section{Measurement equation}

$\log P I B_{t}=\left[\begin{array}{lll}1 & \log \mathrm{X}_{\mathrm{t}} & \log \mathrm{FE}_{\mathrm{t}} \log \text { TOT }_{t}\end{array}\right]\left[\begin{array}{l}\beta_{0 t} \\ \beta_{1 t} \\ \beta_{2 t} \\ \beta_{3 t}\end{array}\right]+e_{t}$

State equation

$$
\left[\begin{array}{l}
\beta_{0 t} \\
\beta_{1 t} \\
\beta_{2 t} \\
\beta_{3 t}
\end{array}\right]=\left[\begin{array}{l}
\alpha \\
0 \\
0 \\
0
\end{array}\right]+\left[\begin{array}{llll}
1 & 0 & 0 & 0 \\
0 & 1 & 0 & 0 \\
0 & 0 & 1 & 0 \\
0 & 0 & 0 & 1
\end{array}\right]\left[\begin{array}{l}
\beta_{0, t-1} \\
\beta_{1, t-1} \\
\beta_{2, t-1} \\
\beta_{3, t-1}
\end{array}\right]+\left[\begin{array}{l}
0 \\
v_{\mathrm{t}} \\
\omega_{\mathrm{t}} \\
\eta_{t}
\end{array}\right]
$$

The coefficients $\beta_{1 t}, \beta_{2 t}$ y $\beta_{3 t}$ are specified as random walks, allowing the disturbances affecting them to have a permanent effect. The augmented Dickey-Fuller test on the sequential coefficients estimated by means of ordinary least squares supports this specification: all the sequential coefficients are I(1) except $\beta_{2 t}$, estimated using a sampling window of 20 observations (lack of space prevents the results from being described in this article). The variances of the disturbances estimated for each state equation $\sigma_{v_{\mathrm{t}}}^{2}, \sigma_{\omega_{\mathrm{t}}}^{2}, \sigma_{\eta_{\mathrm{t}}}^{2}$, known as hyperparameters, indicate whether the coefficient has a stochastic or deterministic trajectory. If the variance is not significantly different from zero, then the coefficient is fixed and does not change over time. As already mentioned, $\beta_{0 t}$ represents the deterministic trend with a constant slope $\alpha$.

\section{Estimation using the Kalman filter}

The state-space system is estimated using the Kalman filter (see appendix B). There is a full description of the Kalman filter in Hamilton (1994) and Kim and Nelson (1999).

Table 5 below shows the result of the estimation, using the Kalman filter, of the coefficients of equation (16) at the end of the period (2005), together with the standard deviation of the disturbances in each state equation. 
TABLE 5

\section{Cuba: estimation using the Kalman filter, period 1950-2005 \\ (Statistical results with the logarithm of data)}

\begin{tabular}{llll}
\hline $\begin{array}{r}\text { Estimation at the end } \\
\text { of the period }(2005)^{\mathrm{b}}\end{array}$ & $\begin{array}{l}\text { Standard deviation } \\
\text { of the disturbances }\end{array}$ \\
\hline$\beta_{0,2005}$ & $6.134^{\mathrm{c}}(0.41)$ & & $0.0062^{\mathrm{c}}$ \\
$\beta_{1,2005}$ & $0.373^{\mathrm{c}}(0.03)$ & $\sigma_{v_{t}}$ & 0.0000 \\
$\beta_{2,2005}$ & $0.139^{\mathrm{c}}(0.02)$ & $\sigma_{\omega_{t}}$ & 0.0236 \\
$\beta_{3,2005}$ & $0.169(0.11)$ & $\sigma_{\eta_{t}}$ & \\
$\alpha$ & $0.026^{\mathrm{c}}(0.006)$ & & \\
$\begin{array}{l}\text { Akaike } \\
\text { information } \\
\text { criterion }\end{array}$ & -2.70 & & \\
\hline
\end{tabular}

Source: Author.

a Model: $\log P I B_{t}=\beta_{0 t}+\beta_{1 t} * \log X_{t}+\beta_{2 t} * \log E_{t}+\beta_{3 t} * \log T O T_{t}+e_{t}$

b Standard error in brackets.

c Significant to $5 \%$.
The table shows that the coefficients for exports and external financing are significant, but this is not so for the coefficient of terms of trade $\beta_{3,2005}$. The slope $\alpha$ of the trend is also significant, with a value of $2.6 \%$, which is the same as the estimation obtained using the ordinary least squares method. The standard deviation of the disturbance associated with the external financing coefficient $\sigma_{\omega_{t}}$ is not significantly different from zero, which indicates that the coefficient has not varied over time. However, the hyperparameters $\sigma_{v_{t}}$ and $\sigma_{\eta_{t}}$ are indeed significant, showing that the coefficients for exports and terms of trade have varied over time, the latter more than the former.

Figure 3 shows the GDP data and the one-periodahead forecast of the Kalman-smoothed estimate. The BPCG model, with time-varying coefficients, can be seen to successfully capture the long-term trajectory of Cuba's GDP. It can even explain the years where GDP

FIGURE 3

Cuba: forecast using the Kalman filter one period ahead of the period 1951-2005 (Logarithm of GDP)

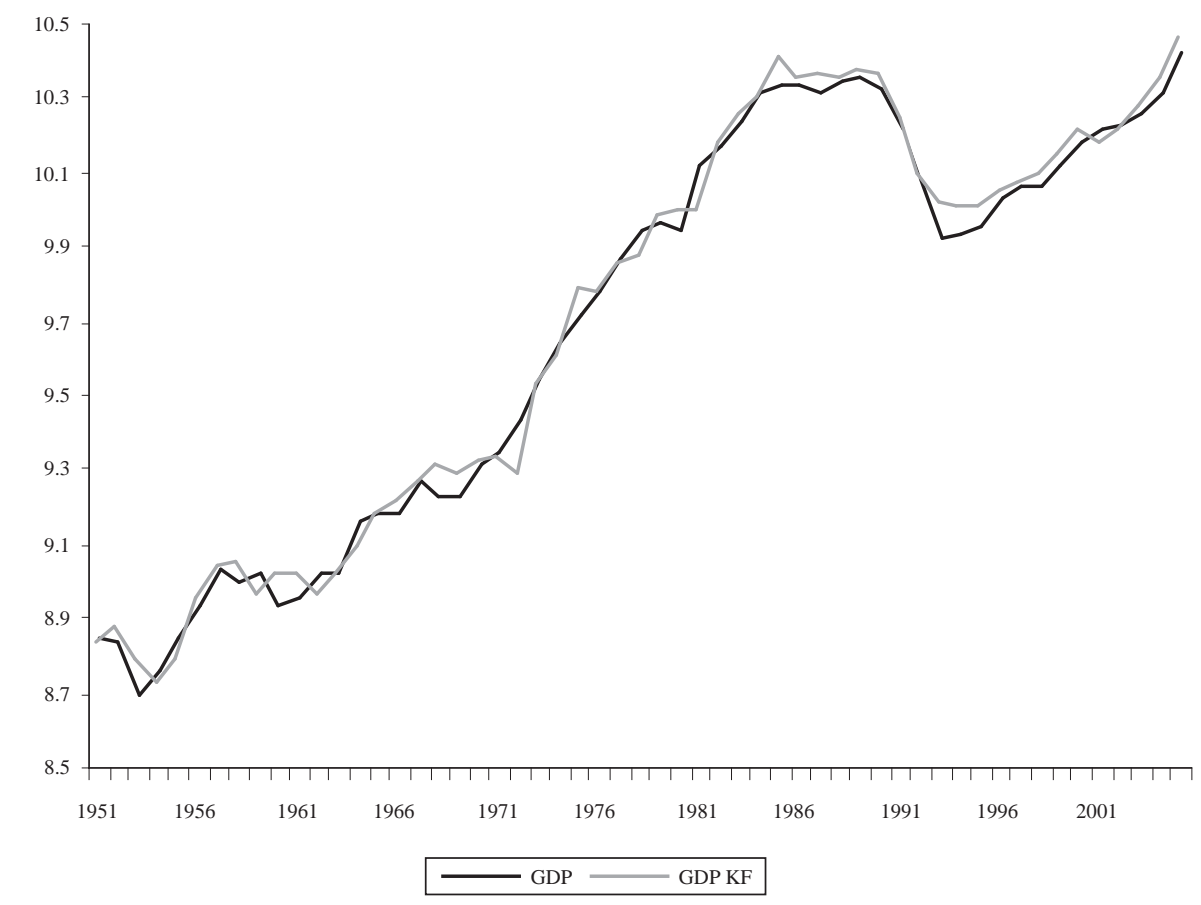

Source: Author.

a Kalman-smoothed estimate. 
fell the most sharply (1990-1993), as well as the rapid growth in GDP in 2004 and 2005. ${ }^{9}$

Figure 4 presents the one-period-ahead forecast errors of the Kalman-smoothed estimate and the residues of the estimated fixed-coefficient model by the ordinary least squares method in the first step of the Engle-Granger estimation. The standard deviation of the former is 0.049 and of the latter, 0.075. The estimation of the BPCG model with time-varying coefficients is shown to be a better predictor than the fixed-coefficient model, especially after 1980.

FIGURE 4

\section{Cuba: one-period-ahead forecast error of the Kalman filter estimate and residues of the ordinary least squares estimate, period 1951-2005 \\ (Statistical results with the logarithm of data)}

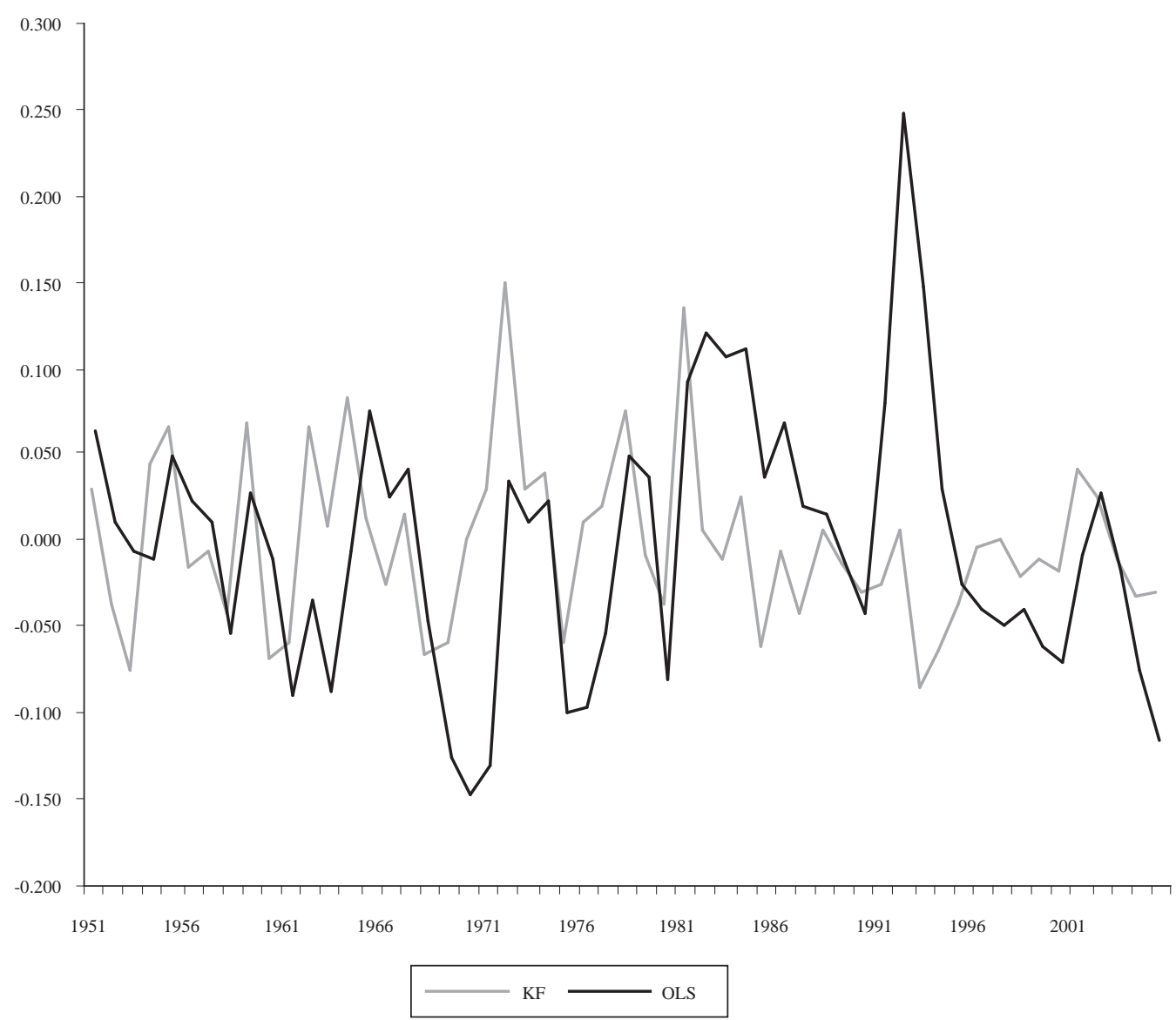

Source: Author.

a Kalman-smoothed estimate and estimation in the first step of the Engle-Granger methodology.

${ }^{9}$ By including external financing and terms of trade, the BPCG model can explain shorter-term GDP movements than Thirlwall's Law can.
However, even in its extended form, balance of payments constrained growth continues to be a long-term concept. 


\section{VI}

\section{Dynamic trade-growth relationship}

\section{Elasticity of GDP to exports and to the terms of trade}

Figure 5 below shows the estimated trajectory, using the Kalman filter, of the time-varying coefficients: the elasticity of GDP to real exports and to the terms of trade. They are smoothed estimates, that is to say, they take into account information for the entire sampling period.
The figure shows that the elasticity of GDP to exports has been more stable than its elasticity to the terms of trade: the former has ranged from a maximum of 0.427 to a minimum of 0.373 , while the latter has ranged from a maximum of 0.313 to a minimum of 0.164 . After averaging around 0.385 from 1950 to 1971 , the elasticity of GDP to exports began to increase in 1972, peaking in 1984; in 1985 it started to fall, bottoming out in 2005. Throughout the period, the elasticity of GDP to exports

FIGURE 5

Estimation of the coefficients using the Kalman filter, trajectory from 1950 to $2005^{a}$ (Statistical results with the logarithm of data)
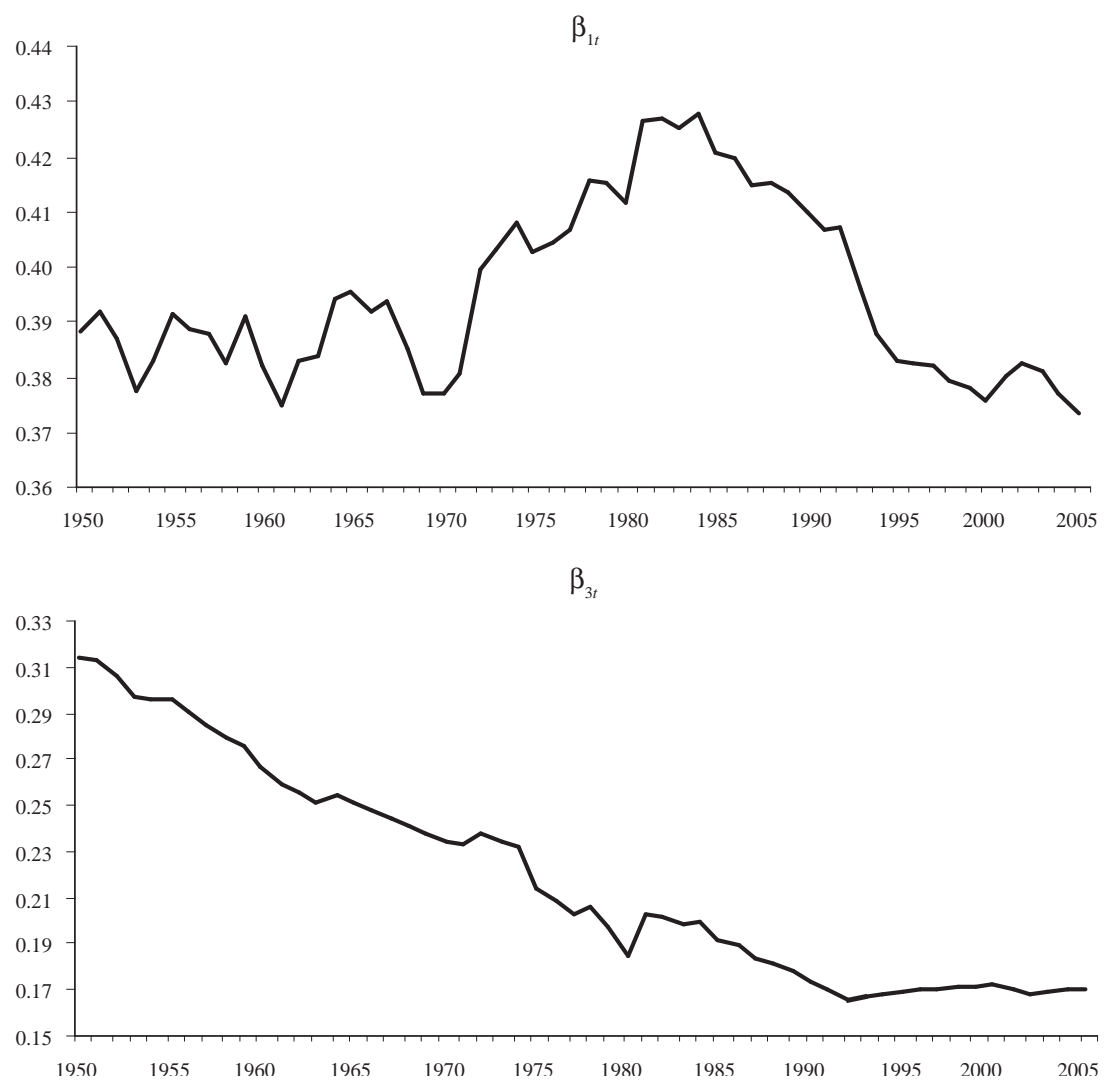

Source: Author.

a Smoothed estimate. Model: $\log G D P_{t}=\beta_{0 t}+\beta_{1 t} * \log X_{t}+\beta_{2 t} * \log E_{t}+\beta_{3 t} * \log T O T_{t}+e_{t}$ 
was greater than its elasticity to external financing and to the terms of trade.

The elasticity of GDP to the terms of trade followed a markedly negative trend virtually throughout the period (figure 5). ${ }^{10}$ In 1993, it stopped falling and started to rise slightly. The negative trend in the $1970 \mathrm{~s}$ and 1980s can be explained by Cuba's agreements with socialist countries and the economy's increased external financing facilities. The inflection point in 1993 coincides with Cuba's reorientation of its foreign trade towards markets where it is more vulnerable to international price variations and is subject to greater financing constraints.

The reduction in the elasticities shows that, in percentage terms, Cuba's GDP derives less benefit (is adversely affected) for every $1 \%$ increase (decrease) in real exports and terms of trade. However, it must be borne in mind that diminished elasticity can be offset by greater variations in exports and in the terms of trade. To gain a better approximation of the effect that the balance of payments has had on Cuba's economic growth, the next section estimates the contribution of each variable to observed GDP growth.

\section{Contribution to growth}

Based on the elasticities of GDP to real exports and to the terms of trade, as well as the fixed elasticity to external financing and the estimated trend growth of $2.6 \%$, a calculation is made of the contribution of each of these variables to GDP growth. To do this, the elasticity (Kalman-smoothed estimate) is multiplied by the observed variation in the explanatory variable in each year. As the relationship is long-run and does not have to occur every year, table 6 shows the results as annual averages for five-year periods and for the entire period. The predicted balance of payments constrained GDP growth is also computed. The contribution of 'other causes' affecting GDP growth but not captured in the model is the difference between observed and predicted GDP growth. ${ }^{11}$

\footnotetext{
${ }^{10}$ This even culminated in the non-significance of the coefficient at the end of the period, as mentioned in respect of table 5.

${ }^{11}$ To be more precise, the contribution of exports in each year is calculated as $\beta_{1 t-1 / T} * d \log X_{t}$ and the contribution of the terms of trade, as $\beta_{3 t-1 / T} * d \log T O T_{t}$. As the coefficient does not change over time, the contribution of external financing is calculated as $0.139 * d \log T O T_{t}$. The contribution of the trend is fixed and equal to $2.6 \%$. To obtain 'other causes', once the annual averages have been calculated, we take the difference between observed and predicted GDP growth (total contributions).
}

The trend makes a fixed contribution of $2.6 \%$, and approximates the contribution of factors that benefit GDP growth and show a trend evolution. The interpretation according to Blecker (1992) would be that the positive trend represents a long-run structural trend and that it increases the relative competitiveness of Cuban goods and services. From a neoclassical standpoint, the trend could be a simplified way of incorporating the longterm impact on GDP of population growth, capital accumulation and technical progress. ${ }^{12}$

Table 6 shows that real exports, external financing and terms of trade explain a large share of the deviations of GDP growth from trend growth. Nevertheless, 'other causes' are also shown to have had a major influence in several five-year periods. The 'other causes' column can approximate the net effect on GDP of factors internal to the economy other than the balance of payments, such as institutional factors and various economic policies. ${ }^{13}$ The existence of negative values in 'other causes' indicates that growth in the Cuban economy is lower than that imposed by external constraints, which means that internal factors are affecting economic growth. The existence of positive values in 'other causes' indicates that the economy has boosted internal factors to overcome the external constraints.

It is worth highlighting a number of results in table 6. In the period 1971-1975, the economy recorded annual average growth above that of trend growth. In this five-year period, with Cuba's entry into the CMEA, terms of trade made a more positive contribution (3.16\%). Together with 'other causes', they were a key factor in higher growth during the five-year periods under analysis. Since that time, the economy has had to struggle with average negative contributions in the terms of trade, which also made a positive contribution of $0.41 \%$ only in the latest period.

\footnotetext{
12 Even using a neoclassical interpretation of the trend, this would not contravene the basic principles of the BPCG model put forward by Thirlwall (1997). We would not be assuming that the factors of production are a sufficient condition for growth and that demand does not matter. On the contrary, we would be assuming that the use of the factors of production depends on there being external demand for the goods produced by Cuba, as well as on the country having foreign exchange receipts to finance imports. The variables of the BPCG model determine whether growth is higher or lower than trend growth.

${ }^{13}$ As the model considers not only exports but also the terms of trade and external financing, we are closer to approximating the effect of factors internal to the economy by studying the differences between observed growth and growth predicted by the BPCG model.
} 
TABLE 6

Cuba: contribution of the explanatory variables, 1951 to 2005

(Annual averages in percentage terms)

\begin{tabular}{|c|c|c|c|c|c|c|c|}
\hline \multirow[t]{2}{*}{ Years } & \multirow{2}{*}{$\begin{array}{c}\text { GDP } \\
\text { (predicted) }\end{array}$} & \multirow{2}{*}{$\begin{array}{c}\text { GDP } \\
\text { (observed) }\end{array}$} & \multicolumn{4}{|c|}{ Contribution of the explanatory variables } & \multirow[t]{2}{*}{ Other causes ${ }^{\mathrm{a}}$} \\
\hline & & & Trend & $\mathrm{X}$ & $\mathrm{FE}$ & TOT & \\
\hline $1951-55$ & 0.64 & 1.25 & 2.60 & -3.57 & 1.73 & -0.12 & 0.61 \\
\hline $1956-60$ & 2.97 & 1.80 & 2.60 & 1.43 & -0.32 & -0.73 & -1.17 \\
\hline $1961-65$ & 2.43 & 5.18 & 2.60 & -0.54 & 1.07 & -0.70 & 2.75 \\
\hline $1966-70$ & 5.20 & 2.63 & 2.60 & 1.67 & 0.13 & 0.81 & -2.58 \\
\hline $1971-75$ & 4.18 & 8.38 & 2.60 & -0.86 & -0.72 & 3.16 & 4.20 \\
\hline $1976-80$ & 3.30 & 4.66 & 2.60 & 0.15 & 0.73 & -0.18 & 1.35 \\
\hline $1981-85$ & 6.12 & 8.04 & 2.60 & 3.50 & 1.69 & -1.68 & 1.92 \\
\hline $1986-90$ & 1.69 & -0.0 & 2.60 & -0.71 & -0.04 & -0.16 & -1.89 \\
\hline $1991-95$ & -3.28 & -7.06 & 2.60 & -2.25 & -1.96 & -1.67 & -3.78 \\
\hline 1996-00 & 5.66 & 4.59 & 2.60 & 3.58 & 0.36 & -0.87 & -1.07 \\
\hline 2001-05 & 4.98 & 4.88 & 2.60 & 3.87 & -1.90 & 0.41 & -0.10 \\
\hline $1951-2005$ & 3.04 & 3.02 & 2.60 & 0.54 & 0.06 & -0.16 & -0.02 \\
\hline
\end{tabular}

Source: Author.

a Difference between observed and predicted growth in the gross domestic product.

The benefits of Cuba's trade and financial agreements with the CMEA started to become apparent in real exports and external financing in the five-year periods 1976-1980 and 1981-1985. Both variables made a positive contribution, which offset the drop in the terms of trade. In the five-year period 1981-1985, external financing made the second largest positive contribution of the period under analysis (1.69\%).

In the five-year periods 1986-1990 and 19911995 , the economy declined as a result of internal and external factors. During those years, the average contribution of all the variables in the BPCG model was negative: the most important external cause during the economic crisis period is considered to be the fall in real exports $(-2.25 \%)$, followed closely by the reduction in external financing $(-1.96 \%)$, and third, by worsening terms of trade $(-1.67 \%)$. Together this led to an average annual drop in GDP of 5.88\% between 1991 and 1995 . In both five-year periods, 'other causes' unrelated to the balance of payments constraints help to explain the fall in GDP, which ties in with the idea that the troubles in the Cuban economy in those years stemmed also from internal factors, which had already been manifesting themselves as problems in the Cuban economic model since the 1980s.

In the five-year periods 1996-2000 and 2001-2005, the Cuban economy resumed annual average growth in excess of trend growth. Real exports were the decisive factor in the economy's recovery following the crisis.

The last row of table 6 shows that, during the 55-year period, observed GDP growth converges with the predicted balance of payments constrained growth. Exports maintain a positive contribution $(0.54 \%)$, the terms of trade make a negative contribution $(-0.16 \%)$ and, as expected, the contribution of external financing tends towards zero, as a current account deficit cannot be maintained indefinitely. ${ }^{14}$

\section{Income elasticity of imports}

In equation (6) of the BPCG theoretical model, the coefficient associated with real exports is given by the expression $\theta / \xi$. Thus, the trajectory of income elasticity of demand for imports $\left(\xi_{t}\right)$ can be obtained based on the trajectory of $\beta_{1 t}$ estimated using the Kalman filter and the observed values of $\theta_{t}$. Figure 6 presents this elasticity calculated by the quotient: $\xi_{t}=\theta_{t} / \beta_{1 t}$.

\footnotetext{
${ }^{14}$ Moreno-Brid and Pérez (2000) showed that the most influential variable in GDP growth in Central American countries during the period 1950-1996 was real exports, rather than the terms of trade (the model does not include external financing).
} 
FIGURE 6

Cuba: trajectory of income elasticity of imports, 1950 to 2005

(Statistical results with the logarithm of data)

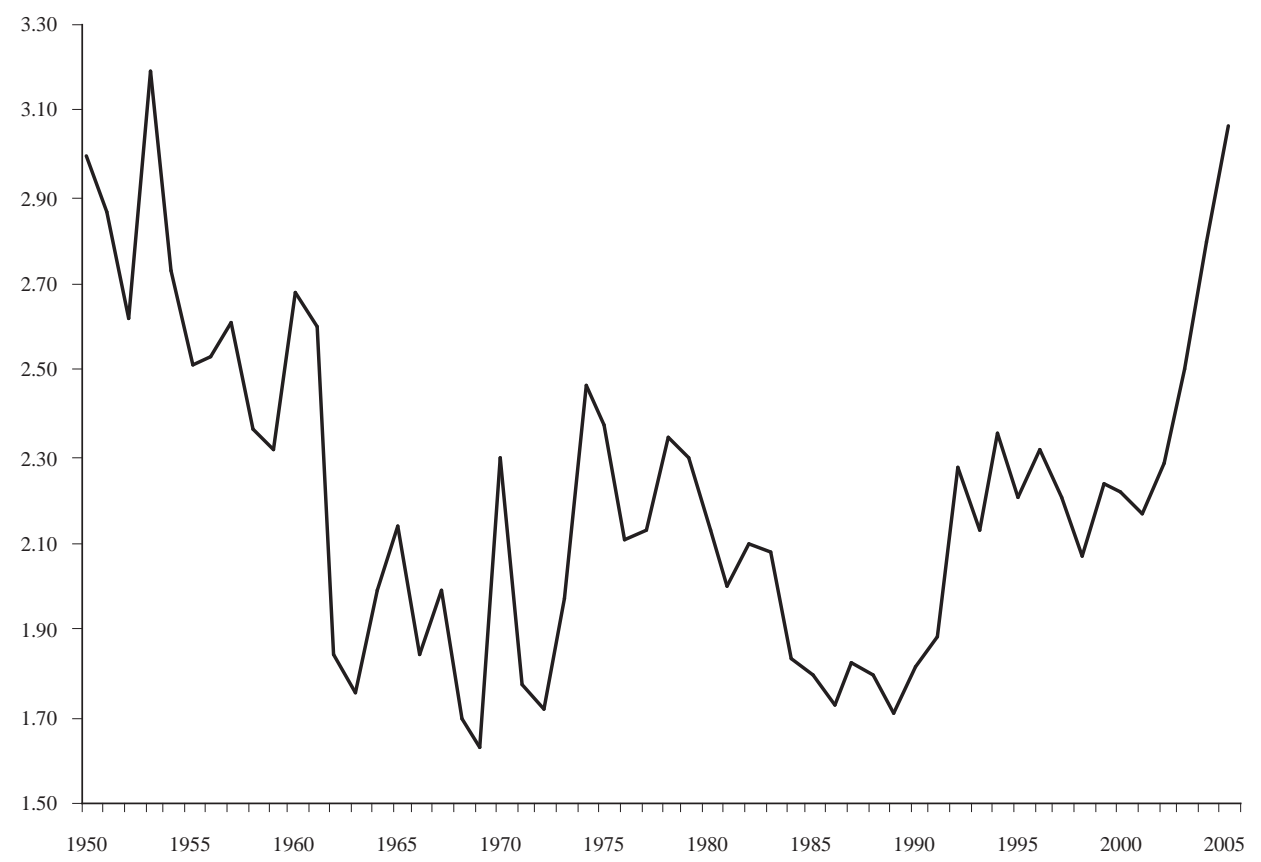

Source: Author.

The figure shows that, in the 1950s and 1960s, income elasticity of imports continued on a downward trend, indicating a process of import substitution. In 1953, it peaked at 3.18 and in 1969 it reached a minimum of 1.62. By around 1974, income elasticity of imports had once again increased to 2.54. It showed a negative trend between 1974 and 1989, the year when it fell to 1.69, again revealing an increase in import substitution. With the economic crisis, there was a new increase in income elasticity of imports between 1990 and 1992. Between 1992 and 2002, it remained at an average of around 2.21. Finally, income elasticity of imports increased significantly between 2003 and 2005, with estimated values of 2.50, 2.79 and 3.06 in the three years, respectively. The elasticity in 2005 is the second highest value in all the 55 years analysed. ${ }^{15}$

${ }^{15}$ Most of the variance of $\xi_{t}$ is given by $\theta_{t}$, since it has a standard deviation 8.4 times greater than $\beta_{1 t}$. The increases and decreases in $\theta_{t}$ have been reflected less in the elasticity of GDP to exports $\beta_{1 t}$ and substantially more in income elasticity of imports $\xi_{t}$.
The estimated trajectory of income elasticity of demand for imports contains most of the estimations made in the aforementioned studies, except MorenoBrid's estimation (2000) of 4.11 for the period 19851998. Mañalich and Quiñones (2004) and Alonso and Sánchez-Egozcue (2005) estimated an income elasticity of imports of 2.88 for the period 1975-2000 and 2.42 for the period 1960-2000, respectively, based on import demand. Mendoza and Robert (2002) and Cribeiro and Triana (2005) estimated elasticities of 1.62 for the period 1976-2000 and 1.72 for the period 1960-2004 respectively, based on the economic growth equation of the BPCG model. 


\section{VII}

\section{Conclusions}

The finding was that the BPCG model with time-varying coefficients can explain much of Cuba's economic growth, even though it was estimated that, in addition to external constraints, internal factors have also had a heavy influence. In accordance with the estimated evolution of elasticities, of all the BPCG model's explanatory variables, real exports have always been the one with the greatest relative impact on GDP. Despite the fact that the elasticity of GDP to exports has been falling since 1985, the surge in exports in the last decade has offset the diminished elasticity. In fact, Cuba's economic growth following the crisis could be said to have been based on rising exports.

The results concur with those of other studies that have applied the BPCG model to Cuba, insofar as they have found economic growth to be highly dependent on imports. Owing to the insufficient domestic supply of intermediate and capital goods, growth in economic activity entails a significant penetration of foreign goods, which exerts pressure on the external equilibrium. The estimated trajectory of income elasticity of demand for imports shows an increase in the early 1990s and between 2003 and 2005, which indicates that import substitution in the Cuban economy has declined.

Despite the high income elasticity of imports, rapid growth in GDP in 2004 and 2005 did not undermine the external equilibrium. The rise in service exports outstripped that of imports, even producing a current account surplus. The combination of higher exports and lower import substitution demonstrates that the export sector has few linkages with the domestic production sector. To some extent this is an expected result: exports of services do not have as much of a multiplier effect as they could do; for example, exports based on industrial sector development. An additional two factors must be determining this result: (i) the slowdown in tourism (the service sector with the largest potential multiplier effect on construction and other domestic production activities), and (ii) falling share of total exports of the sugar sector (a sector that has tends to have more linkages with other national production sectors). As part of the process for restructuring the Cuban sugar agroindustry, almost half of the country's industrial sugar mills were shut down in 2002, and 2005 saw the smallest sugarcane harvest for the past 100 years.

The estimation of the BPCG model suggests that the future growth of the Cuban economy will depend chiefly on the ability to maintain export growth and to reduce income elasticity of demand for imports. Given the new economic agreements with Venezuela and China and the rapid increase in professional services, exports are expected to continue growing in the coming years. However, prospects could be better and bring benefits to a larger proportion of the economy if import substitution were made more efficient and if other export sectors with a greater multiplier effect were expanded. 
APPENDIX A

Transformation of external financing

FIGURE A.1

Evolution of the actual external financing series, 1950-2005a

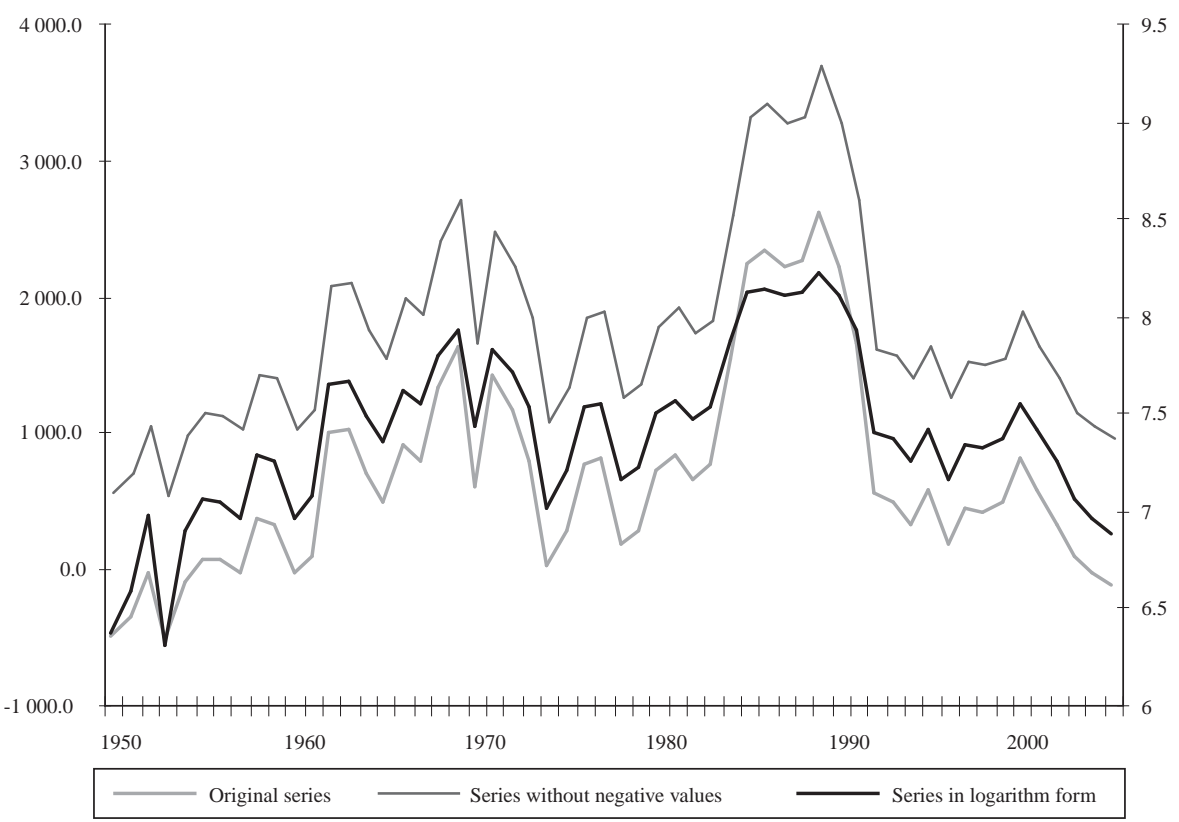

Source: Author, on the basis of data from Cuba's National Statistical Office (ONE) and its National Institute of Economic Research (INIE).

a Left vertical axis: original series and series without negative values. Right vertical axis: series in logarithm form.

APPENDIX B

Kalman filter algorithm

The Kalman filter was developed by Rudolf E. Kalman (1960). It is the main algorithm for estimating dynamic systems represented in state-space form. It works using a recursive procedure that allows the optimum estimator of the state vector to be obtained at each moment in time $t$ based on the information available up to that time. The estimator is optimum in the sense that it minimizes the average quadratic error. Depending on how much information is used, there is either the basic or the smoothed Kalman filter. The basic filter is an estimation of the state vector using the information available up to time $t$. The smoothed filter is an estimation of the state vector based on the information available throughout the sampling period $T$.

\section{The basic filter}

The basic filter is based on a prediction and correction algorithm of vector $\beta_{t}$, which is repeated for each observation from the beginning to the end of the sample.

\section{a) Prediction}

On the basis of the information available up to the moment in time $\mathrm{t}-1$ referring to $\beta_{t / t-1}$, a prediction is made of $y_{t}: y_{t / t-1}$.

b) Correction

Once $y_{t}$ is known, it is possible to calculate the 
prediction error: $\eta_{t / t-1}=y_{t}-y_{t / t-1}$. This prediction error contains new information on $\beta_{t}$ not contained in $\beta_{t / t-1}$. Thus, after observing $y_{t}$, a more precise inference is made of $\beta_{t}$. Vector $\beta_{t / t}$, an inference of $\beta_{t}$ based on information up to time $\mathrm{t}$, is obtained as follows: $\beta_{t / t}=\beta_{t / t-1}+K_{t} \eta_{t / t-1}$, where $K_{t}$ is the weight assigned to the new information on $\beta_{t}$ contained in the prediction error, which is known as the 'Kalman gain'.

\section{c) Equations}

\section{(i) Prediction equations}

Prediction of state: $\beta_{t / t-1}=\mu+F_{t} \beta_{t-1 / t-1}$

Covariance prediction of $\beta_{t}$ :

$P_{t / t-1}=F P_{t-1 / t-1} F^{\prime}+Q$

Prediction error:

$\eta_{t / t-1}=y_{t}-y_{t / t-1}=y_{t}-x_{t} \beta_{t / t-1}$

Prediction error variance:

$f_{t / t-1}=x_{t} P_{t / t-1} x^{\prime}+R_{t}$

where $Q$ is the covariance of the effects of the disturbances on $\beta_{t}$ and $R$ is the variance of the error $e_{t}$ of the measurement equation.

(ii) Correction equations

State correction: $\beta_{t / t}=\beta_{t / t-1}+K_{t} \eta_{t / t-1}$
Covariance correction:

$$
P_{t / t}=P_{t / t-1}-K_{t} x_{t} P_{t / t-1}
$$

where $K_{t}=P_{t / t-1} x_{t}{ }^{\prime} f^{-1}{ }_{t / t-1}$ is the Kalman gain.

Given the initial values of $\beta_{0 / 0}$ and its variance $P_{0 / 0}$, the equations of the basic filter are iterated by $t=1,2, \ldots, T$. This article takes as initial values the fixed coefficients and the variances in equation (13) estimated by the ordinary least squares method with the first 35 observations in the first step of the EngleGranger methodology.

\section{Smoothed filter}

The smoothed filter $\beta_{t / T}$ provides a more precise estimation of $\beta_{t}$ since it uses more information than the basic filter. It is based on the same prediction and correction procedure, which uses the basic filter but ahead of the time, for $t=T-1, T-2, \ldots, 1$, taking as initial values the values obtained from the last iteration of the basic filter.

\section{Smoothing procedure equations}

$$
\begin{gathered}
\beta_{t / T}=\beta_{t / t}+P_{t / t} F^{\prime} P_{t+1 / t}^{-1}\left(\beta_{t+1 / T}-F \beta_{t / t}-\tilde{\mu}\right) \\
P_{t / T}=P_{t / t}+P_{t / t} F^{\prime} P_{t+1 / t}^{-1}\left(P_{t+1 / T}-P_{t+1 / t}\right) P_{t+1 / t}^{-1}{ }^{\prime} F P_{t / t}^{\prime}
\end{gathered}
$$

(Original: Spanish)
Alonso, José Antonio and Jorge Mario Sánchez-Egozcue (2005): La competitividad desde una perspectiva macro: la restricción externa al crecimiento, Tecnología, competitividad y capacidad exportadora de la economía cubana: el desafío de los mercados globales, Havana.

Álvarez, Fernando, Miguel Dorta and José Guerra (2000): Persistencia inflacionaria en Venezuela: evolución, causas e implicaciones, documento de trabajo, No. 26, Caracas, Central Bank of Venezuela.

Atesoglu, H.S. (1993-1994): Exports, capital flows, relative prices and economic growth in Canada, Journal of Post Keynesian Economics, vol. 16, No. 2, New York, M.E. Sharpe.

(1997): Balance-of-payments-constrained growth model and its implications for the United States, Journal of Post Keynesian Economics, vol. 19, No. 3, New York, M.E. Sharpe.

Bairam, B. (1993): Static versus dynamic specification and the Harrod foreign trade multiplier, Applied Economics, vol. 25, No. 6, London, Taylor \& Francis.
Blecker, R.A. (1992): Structural roots of U.S. trade problems: income elasticities, secular trends and hysteresis, Journal of Post Keynesian Economics, vol. 14, No. 3, New York, M.E. Sharpe.

Cribeiro, Yordanka and Lilian Triana (2005): Las elasticidades en el comercio exterior cubano: dinámica de corto y largo plazo, tesis de diploma, Havana, University of Havana.

Engle, R. and C. Granger (1987): Co-integration and error-correction. Representation, estimation, and testing, Econometrica, vol. 55, No. 2, New York, Econometric Society, March.

Engle, R. and Byung Sam Yoo (1987): Forecasting and testing in co-integrated systems, Journal of Econometrics, vol. 35, No. 1, North-Holland, Elsevier Science Publishers B.V.

Haldane, A.G. and S.G. Hall (1991): Sterling's relationship with the dollar and the Deutschemark: 1976-89, The Economic Journal, vol. 101, Oxford, Blackwell Publishing, May.

Hamilton, James D. (1994): Time Series Analysis, Princeton, Princeton University Press. 
Hussain, M.N. (1999): The Balance-of-Payments Constraint and Growth Rate Differences among Africa and East Asian Economies, African Development Review, vol. 11, No. 1, Oxford, African Development Bank, Blackwell Publishing.

Johansen, S. (1991): Estimation and hypothesis testing of cointegration vectors in Gaussian vector autoregressive models, Econometrica, vol. 59, No. 6, New York, Econometric Society.

(1995): Likelihood-basedIinference in Cointegrated Vector Autoregressive Models, Oxford, United Kingdom, Oxford University Press.

Johansen, S. and K. Juselius (1990): Maximum likelihood estimation and inferences on cointegration with applications to the demand for money, Oxford Bulletin of Economics and Statistics, vol. 52, No. 2, Oxford, United Kingdom, Oxford University Press.

Kalman, R.E. (1960): A new approach to linear filtering and prediction problems, Journal of Basic Engineering, vol. 82, No. 1, New York, American Society of Mechanical Engineering.

Kim, Chang-Jin and Charles Nelson (1999): State-Space Models with Regime Switching, Massachusetts, MIT Press.

Mañalich, Isis and Nancy Quiñones (2004): Sustitución de importaciones. Un desafío impostergable, Havana, University of Havana.

McCombie, J.S.L. (1997): On the empirics of balance-of-paymentsconstrained growth, Journal of Post Keynesian Economics, vol. 19, No. 3, New York, M.E. Sharpe.

McCombie, J.S.L. and A.P. Thirlwall (1994): Economic Growth and the Balance-of-Payments Constraint, New York, St. Martin's Press.

Mendoza, Yenniel and Leonel Robert (2002): El crecimiento económico y las restricciones en el sector externo. Una aplicación al caso cubano, Havana, Instituto Nacional de Investigaciones Económicas, unpublished.

Moreno-Brid, Juan Carlos (1998-1999): On capital flows and the balance-of-payments-constrained growth model, Journal of Post Keynesian Economics, vol. 21, No. 2, New York, M.E. Sharpe.

(1999): Mexico's economic growth and the balance of payments constraint: a cointegration analysis, International
Review of Applied Economics, vol. 13, No. 2, London, Taylor $\&$ Francis.

(2000): Crecimiento económico y escasez de divisas, $L a$ economía cubana. Reformas estructurales y desempeño en los noventa, Mexico City, ECLAC/Fondo de Cultura Económica.

(2003): Capital flows, interest payments and the balanceof-payments constrained growth model: a theoretical and empirical analysis, Metroeconomica vol. 54, Oxford, United Kingdom, Blackwell Publishing.

Moreno-Brid, Juan Carlos and Esteban Pérez (2000): Balanza de pagos y crecimiento en América Central, 1950-1996, Comercio exterior, vol. 50, No. 1, México, D.F., Banco Nacional de Comercio Exterior, January.

Moreno-Brid, Juan Carlos and Carlos Ricoy (2005): New measurement tools of the external-constrained growth model, with applications for Latin America, in Jacek Leskow, Martín Puchet and Lionello Punzo (eds.), New Tools of Economic Dynamics, Lectures Notes in Economics and Mathematial Systems No. 551, New York, Springer.

Nelson, Charles and Chang-Jin Kim (1988): The time-varyingparameter model as an alternative to ARCH for modeling changing conditional variance: the case of Lucas hypothesis, NBER Technical Working Paper, No. 70, Cambridge, Massachusetts, National Bureau of Economic Research.

Perron, P. (1989): The great crash, the oil price shock, and the unit root hypothesis, Econometica, vol. 57, No. 6, New York, The Econometric Society, November.

Revenga, A. (1993): Credibilidad y persistencia de la inflación en el Sistema Monetario Europeo, documento de trabajo, No. 9.321, Madrid, Bank of Spain.

Thirlwall, A.P. (1979): The balance of payments constraint as an explanation of international growth rate differences, Quarterly Review, Rome, Banca Nazionale del Lavoro, March.

(1997): Reflections on the concept of balance-of-paymentsconstrained growth, Journal of Post Keynesian Economics, vol. 19, No. 3, New York, M.E. Sharpe.

Thirlwall, A.P. and M.N. Hussain (1982): The balance of payments constraint, capital flows and growth rates differences between developing countries, Oxford Economic Papers, No. 34, Oxford, United Kingdom, Oxford University Press. 